\section{Summary}

Human duodenal mucosal cells have been examined by mixed-cell agglutination for the presence of bloodgroup antigens.

The secretor status of the patients has been determined, and in a proportion of cases gastric juice as well as saliva has been studied. Mixed-cell agglutination has also been performed on the buccal cells from a percentage of subjects as a control of technique.

The results indicate that antigen is present in secretor subjects, but is absent or very scanty in at least a proportion of non-secretor individuals.

The possible relevance of this finding to the problem of duodenal ulcerogenesis is examined.

This work formed part of a project the results of which were submitted as a thesis for the degree of M.D. of the University of Liverpool. I am grateful to Dr. R. R. A. Coombs, Dr. C. A. Clarke, and Dr. R. B. McConnell for their help and suggestions, and to Mr. W. T. A. Donohoe, who carried out the serological testing of the saliva and gastric-juice specimens.

\section{REFERENCES}

Aird, I., Bentall, H. H., Mehigen, J. A., and Roberts, J. A. F. (1954). Brit. med. J., 2, 315

Cain, A. J. (1957). Lancet, 1, 212

Clarke, C. A. (1961). Progress in Medical Genetics, Chapter 4. Grune and Stratton, London.

Edwards, J. W., Haddock, D. R. W., Howel-Evans, A. W. McConnell, R. B., and Sheppard, P."M. (1956). Brit. med. J., 2, 725

Evans, D. A. P. McConnell, R. B., and Sheppard, P. M (1959) Ibid., 1, 603

Coombs, R. R. A., Bedford, D., and Rouillard, L. M. (1956) Lancet, 1, 461 .

Cowan, W. K. (1962) J. Path. Bact In press.

Doll, R., Drane, H., and Newell, A. C. (1961). Gut, 2, 352

Glynn, L. E., Holborow, E. J., and Johnson, G. D. (1957) Lancet, 2. 1083.

Holborow, E. J., Brown, P. C., Glynn, L. E., Hawes, M. D., Gresham, G. A., O'Brien, T. F. and Coombs, R. R, A (1960). Brii. J.exp. Path., 41, 430

Lawle,, S. (1957). Demonstration at Genetical Society Meeting, John Innes Horticultural Institution.

McConnell, R. B. (1459). Gastroenterologia (Basel), 92, 103.

Race, R. R., and Sanger, R. (1958). Blood Groups in Man. Blackwell, Oxford.

Selsnick, F. (1959). Ch.M. thesis, University of Liverpool.

Swinburne, L. M., Frank, B., and Coombs, R. R. A. (1961). Vox Sang (Basel), 6, 274

Szulman, A. E. (1960). J. exp. Med., 111, 785.

\title{
INFLUENCE OF THE SECRETOR AND LEWIS GENES ON SUSCEPTIBILITY TO DUODENAL ULCER
}

\section{P. A. J. BALL, M.D., M.R.C.P. \\ West African Medical Research Fellow, Department of Medicine, University College Hospital, Ibadan, Nigeria}

In all series so far published it has been found that people of blood group $\mathrm{O}$ and non-secretors of the ABO blood-group substances suffer from duodenal ulcer more often than the rest of the population (Doll et al., 1961). This paper describes an attempt to define the way in which non-secretion affects susceptibility to duodenal ulcer.

The secretor gene has no known direct expression, but exerts its effects on the composition of the mucous secretions of the body by interaction with the $A B O$ and Lewis genes, all three genes being inherited independently of each other. The saliva of all secretors contains $H$ antigen, and that of blood group $A, B$, and $A B$ secretors A, B, or both; the saliva of non-secretors lacks ABO specificity. The relationship between the secretor and Lewis genes is less well understood. The simplest explanation of the known facts is that possession of the Lewis gene, which confers the ability to synthesize Le $^{\text {a }}$ substance, a mucopolysaccharide closely related to the ABO blood-group substances, is inherited as a dominant character. The saliva of people who are genetically capable of synthesizing Le $\mathrm{e}^{\mathrm{a}}$ substance usually contains very much more of the substance if they are $\mathrm{ABO}$ non-secretors (with the red-cell phenotype $\operatorname{Le}(a+b-))$ than if they are secretors (red-cell phenotype $\operatorname{Le}(a-b+))$, perhaps because in secretors the $\mathrm{ABO}$ gene has priority in determining the chemical nature of a limited available quantity of water-soluble mucopolysaccharide (Race and Sanger, 1959). Persons who are genetically incapable of synthesizing $\mathrm{Le}^{\mathrm{a}}$ substance all have the red cell phenotype $\operatorname{Le}(a-b-)$, and secrete at most traces of the substance in their saliva or other mucous secretions.

It follows that there are at least three possible causes for an excess of non-secretors among patients with duodenal ulcer. (1) The absence of $\mathrm{ABO}$ specificity in mucus is disadvantageous by comparison with its presence. (2) Some other as yet unknown expression of the secretor gene influences susceptibility to ulceration. (3) Both the Lewis and secretor genes are involved. An excess of non-secretors would result if $\operatorname{Le}(a+b-)$ persons were more susceptible to duodenal ulcer than $\operatorname{Le}(a-b+)$ or $\operatorname{Le}(a-b-)$ persons.

In the first two cases the Lewis gene system will not be involved, and the relative numbers of subjects with and without the Lewis gene will be the same among patients with duodenal ulcer as in the general population. In the third case any excess of non-secretors should be made up entirely of $\operatorname{Le}(a+b-)$ subjects, and there should be both relatively and absolutely fewer non-secretors who are $\operatorname{Le}(\mathrm{a}-\mathrm{b}-)$ among patients with duodenal ulcer than among healthy people.

It should be possible to distinguish between these alternatives by comparing the frequencies of the different Lewis phenotypes in subjects with and without duodenal ulcer. This cannot easily be done in Europe, where only about $6 \%$ of the population is $\operatorname{Le}(a-b-)$. Some $35 \%$ of West Africans are Le $(a-b-)$, however, and this paper describes such a comparison between Nigerians belonging to a single tribe.

\section{Material}

The ABO group, secretor status, and Lewis phenotype have been determined in 172 male patients of the Yoruba tribe with duodenal ulcer. They all gave a suggestive history and had radiological evidence of chronic ulceration, and the diagnosis was confirmed at operation in 106 of them. In addition, the $\mathrm{ABO}$ group was known in 218 of a further 229 Yoruba patients of both sexes who were operated upon for duodenal ulcer in this hospital between 1957 and 1960. 
Investigation of secretor status and Lewis phenotype was restricted to male patients because it is doubtful whether the titres of blood-group substances in saliva are the same in men and women (Doll et al., 1961), and too few women were seen to justify separate comparison. The following controls were used:

(1) 26,027 Yoruba blood donors who have attended the blood transfusion department at the hospital.

(2) 300 male Yoruba subjects. These men were patients or their relatives attending the main reception clinic of the hospital, at which nearly all the patients with duodenal ulcer had initially been seen. None of them complained of symptoms suggesting that they might have a duodenal ulcer. Their secretor status was determined, and the Lewis phenotype of all nonsecretors and of 75 secretors.

\section{Methods}

The $\mathrm{ABO}$ groups were determined by a standard tube technique.

Secretor status was determined by the effect of undiluted saliva in inhibiting agglutination by Ulex extract (anti-H), and anti-A and anti-B grouping sera. All the samples were tested for the presence of $H$ antigen ; the saliva of all the controls, and of patients who were not of group $\mathrm{O}$, was also tested for $\mathrm{A}$ and $\mathrm{B}$.

The Lewis group was determined from the saliva. The presence of Le $\mathrm{L}^{\mathrm{a}}$ substance was detected by its action in inhibiting the effect of lytic anti-Le ${ }^{a}$ sera on papainized cells. Samples of saliva were heated for 15 minutes in a boiling-water bath within one hour of collection and stored at $-20^{\circ} \mathrm{C}$. They were centrifuged immediately before use. Two volumes of a 1 in 12 solution of Löw's papain in phosphate buffer $(p H$ 7.3) and one volume of group $\mathrm{O} \operatorname{Le}(\mathrm{a}+\mathrm{b}-)$ red cells were incubated at $37^{\circ} \mathrm{C}$. for 15 minutes; the cells were washed, and were used on the same day. One drop of antiserum was added to one drop of diluted saliva, and after 15 minutes at room temperature one drop of $5 \%$ papainized cells was added. The tubes were incubated at $37^{\circ} \mathrm{C}$. for between half and one hour and the results read without centrifuging. The antiserum always caused complete haemolysis when diluted $1: 2$ with saline, and inhibition was recorded as being present only if no visible haemolysis had occurred.

Secretor saliva was tested at a dilution of $1: 5$ and $1: 10$. Non-secretor saliva was tested at $1: 5,1: 10$, $1: 20,1: 100,1: 200$, and $1: 1,000$. Antiserum from the same donor was used to test all the non-secretor samples, but secretor saliva was tested with one or more of three different antisera. Many samples of non-secretor saliva were also checked against all three antisera; although the inhibitory titre sometimes varied, the apparent Lewis group was always the same. Red cells from the same donor were used throughout.

\section{Results \\ ABO Group}

The ABO group of the 172 patients with duodenal ulcer is shown in Table I, together with their secretor status and Lewis phenotype.

Table II shows the combined frequencies of the ABO groups in these patients and in the 218 other patients operated upon between 1957 and 1960, compared with the frequencies found in the control blood donors.
Of the patients with duodenal ulcer $60.3 \%$ belonged to group $\mathrm{O}$, compared with $51.5 \%$ of the controls $\left(\chi^{2}=11.75, \mathrm{n}=1, \mathrm{P}<0.001\right)$.

TABLE I.-The ABO Group, Secretor Status, and Lewis Phenotype of 172 Male Yoruba Patients with Duodenal Ulcer

\begin{tabular}{lc|c|c|c|c|c|c}
\hline & & $\mathbf{O}$ & $\mathbf{A}$ & $\mathbf{B}$ & $\mathbf{A B}$ & Total & $\%$ \\
\hline Le(a-b+) & $\cdots$ & 36 & 10 & 10 & 4 & 60 & $34 \cdot 9$ \\
Le(a-b-) & $\ldots$ & 30 & 9 & 9 & 0 & 48 & $27 \cdot 9$ \\
Total secretors & 6 & 66 & 19 & 19 & 4 & 108 & $62 \cdot 8$ \\
\hline Le(a+b-) & $\ldots$ & 28 & 13 & 9 & 1 & 51 & $29 \cdot 6$ \\
Le(a-b-) & 6 & 4 & 3 & 0 & 13 & $7 \cdot 6$ \\
Total non-secretors & 34 & 17 & 12 & 1 & 64 & $37 \cdot 2$ \\
\hline
\end{tabular}

TABLE II.-The ABO Group of 390 Yoruba Patients with Duodenal Ulcer Compared with 26,027 Yoruba Blood Donors

\begin{tabular}{|c|c|c|c|c|c|}
\hline & O & A & B & AB & Total \\
\hline 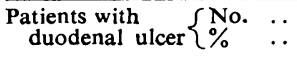 & $\begin{array}{l}235 \\
60 \cdot 3\end{array}$ & $\begin{array}{c}75 \\
19 \cdot 2\end{array}$ & $\begin{array}{c}72 \\
18 \cdot 5\end{array}$ & $\begin{array}{c}8 \\
2 \cdot 0\end{array}$ & 390 \\
\hline $\begin{array}{c}\begin{array}{c}\text { Control blood } \\
\text { donors }\end{array} \\
\text { No. }\end{array} \quad \ldots$ & $\begin{array}{c}13,411 \\
51 \cdot 5\end{array}$ & $\begin{array}{l}5,559 \\
21 \cdot 3\end{array}$ & $\begin{array}{l}6,038 \\
23 \cdot 3\end{array}$ & $\begin{array}{c}1,019 \\
3 \cdot 9\end{array}$ & 26,027 \\
\hline
\end{tabular}

\section{Secretor Status}

The secretor status of the 300 male control subjects is shown in Table III, together with their Lewis phenotype. Of the patients with duodenal ulcer $37.2 \%$ were non-secretors of ABO blood-group substances, compared with $25.3 \%$ of the controls $\left(\chi^{2}=6.83, \mathrm{n}=1\right.$, $\mathbf{P}<0.01)$.

TABLE III.-The Secretor Status and Lewis Group of 300 Male Yoruba Control Subjects

\begin{tabular}{|c|c|c|c|}
\hline & & No. of Patients & $\%$ \\
\hline $\begin{array}{l}\text { Le }(a-b+) \quad \ldots \\
\text { Le(a-b-) } \quad . \\
\text { Total secretors }\end{array}$ & $\begin{array}{ll}\cdots & \cdots \\
\cdots & \cdots\end{array}$ & $\left.\begin{array}{r}47 \\
28 \\
224\end{array}\right\}^{\text {of } 75}$ tested & $74 \cdot 7$ \\
\hline $\begin{array}{l}\operatorname{Le}(a+b-) \quad \ldots \\
\text { Le(a-b-) } \quad \ldots \\
\text { Total non-secretors }\end{array}$ & $\begin{array}{l}\cdots \\
\cdots \\
\end{array}$ & $\begin{array}{l}47 \\
29 \\
76\end{array}$ & $\begin{array}{r}15 \cdot 6 \\
9 \cdot 7 \\
25 \cdot 3\end{array}$ \\
\hline
\end{tabular}

\section{Lewis Phenotype}

The highest dilutions at which the samples of saliva caused inhibition of anti-Le ${ }^{a}$ serum are shown in Table IV. Any sample which failed to inhibit the antiserum at a dilution of $1: 5$ was recorded as being $\operatorname{Le}(a-b-)$. All the samples from secretors which inhibited at $1: 5$ also did so at $1: 10$, and were recorded as $\operatorname{Le}(a-b+)$. The samples from the non-secretors which inhibited at $1: 5$ all inhibited to a titre of $1: 20$ or higher, and were recorded as $\operatorname{Le}(a+b-)$. The wide variation in titre among the samples from $\operatorname{Le}(a+b-)$ subjects corresponds with the findings of other workers (Brendemoen, 1949 ; Miller et al., 1954 ; Brown et al., 1959).

There was a relatively greater number of $\operatorname{Le}(a+b-)$ subjects among the non-secretors with duodenal ulcer than among the control non-secretors $\left(x^{\prime \prime}=4.45, n=1\right.$, $0.02<\mathrm{P}<0.05)$. It can be seen in Table I that the excess

TABLE IV - 172. Male Patients with Duodenal Ulcer and 300 Male Control Patients, Showing the Highest Titre at which their Saliva Inhibited Lysis of Le(a+) Cells by Anti-Lea Serum

\begin{tabular}{|c|c|c|c|c|c|c|c|c|}
\hline & $<1 / 5$ & $1 / 5$ & $1 / 10$ & $1 / 20$ & $1 / 100$ & $1 / 200$ & $1 / 1,000$ & Total \\
\hline $\begin{array}{l}\mathrm{ABO} \\
\text { secretors }\end{array}\left\{\begin{array}{l}\text { D.U. } \\
\text { Controis }\end{array}\right.$ & $\begin{array}{l}48 \\
28\end{array}$ & $\begin{array}{l}\mathbf{0} \\
\mathbf{0}\end{array}$ & $\begin{array}{l}60 \\
47\end{array}$ & & & & & $\begin{array}{r}108 \\
75\end{array}$ \\
\hline$\underset{\text { secretors }}{\mathrm{ABO} \text { non- }}\left\{\begin{array}{l}\text { D.U. } \\
\text { Controls }\end{array}\right.$ & $\begin{array}{l}13 \\
29\end{array}$ & $\begin{array}{l}\mathbf{0} \\
\mathbf{0}\end{array}$ & $\begin{array}{l}0 \\
0\end{array}$ & $\begin{array}{l}4 \\
6\end{array}$ & $\begin{array}{l}2 \\
3\end{array}$ & $\begin{array}{l}5 \\
8\end{array}$ & $\begin{array}{l}40 \\
30\end{array}$ & $\begin{array}{l}64 \\
76\end{array}$ \\
\hline
\end{tabular}

Saliva from $A B O$ secretors was tested at a dilution of $1: 5$ and $1: 10$ only. There were altogether 224 control secretors, of whom 75 were tested. 
of $\mathrm{ABO}$ non-secretors among the patients with duodenal ulcer was entirely accounted for by the large number of patients who were $\operatorname{Le}(a+b-)$. The expected number of Le $(a-b-)$ non-secretors was 17 , and only 13 were found. Among secretors, on the other hand, there was no abnormal preponderance of $\operatorname{Le}(a-b+)$ over $\operatorname{Le}(a-b-)$ patients, and their relative numbers did not differ significantly from the controls $\left(\chi^{2}=0.63, n=1\right.$, $\mathrm{P}>0.3$ ).

It can be seen in Table IV that the saliva of $\operatorname{Le}(a+b-)$ patients with duodenal ulcer inhibited the antiserum to a titre of $1: 1,000$ more often than that of $\operatorname{Le}(a+b-)$ controls. Only one sample was tested from each subject, however, and the numbers are too small to justify any conclusion from this difference.

\section{Discussion}

These results suggest that the Lewis gene influences susceptibility to duodenal ulcer. People who possess the Lewis gene are apparently only abnormally predisposed to duodenal ulcer when they are also ABO non-secretors. Conversely, absence of the secretor gene appears only to be disadvantageous in subjects who possess the Lewis gene. Clearly this work needs to be repeated elsewhere, and no confidence can be placed in a single study. If the results are confirmed, however, they suggest that susceptibility to duodenal ulcer is not affected by either the secretor or Lewis genes acting alone, but by their interaction.

The relative frequencies of the different Lewis phenotypes in the control subjects (Table III) agree well with those found by Barnicot and Lawler (1953) in Lagos. Of 141 people of several tribes whose red cells they tested for Lea specificity $21(14.9 \%)$ were $\operatorname{Le}(\mathrm{a}+) ; 86$ of their Le $(\mathrm{a}-)$ subjects who belonged to group $\mathrm{O}$ or $\mathrm{A}$ were tested with anti-Le ${ }^{b}$ serum, and 45 proved to be $\operatorname{Le}(a-b+)$.

The distribution of the Lewis phenotypes in patients with duodenal ulcer has previously been studied by Clarke et at. (1956) in Liverpool. A relative deficiency of Le $(\mathrm{a}-)$ patients was found among male non-secretors. Among female patients, on the other hand, they found a considerably greater frequency of non-secretors than among men, and more than the expected proportion were $\operatorname{Le}\left(a_{-}\right)$. There were too few patients of either sex for these differences to be statistically significant.

Secretor status and Lewis group appear to affect the likelihood of a person's developing a duodenal ulcer rather more than does the ABO group. Woolf (1955) showed how the liability to disease of subjects of a particular blood group could best be expressed by comparison with the liability of persons of a blood group thought not to predispose to the disease in question. When Woolf's method is applied to the patients described here, patients of group $\mathrm{O}$ are found to have suffered from duodenal ulcer 1.43 times more often than patients of groups $\mathrm{A}, \mathrm{B}$, and $\mathrm{AB}$ combined (with $95 \%$ confidence limits between 1.17 and 1.76). ABO non-secretors were 1.74 times more liable than secretors (1.16-2.62), and $\operatorname{Le}(a+b-)$ subjects were 2.26 times more liable than subjects belonging to the other Lewis phenotypes considered together $(95 \%$ confidence limits between 1.42 and 3.61 ).

If susceptibility to duodenal ulcer is affected by interaction of the secretor and Lewis genes in the manner proposed above, it is likely that the immediate factor responsible is a difference between $\operatorname{Le}(a+b-)$ and other people in the character of their gastrointestinal mucus. Evidence has been presented by Clarke et al. (1959) and by Evans (1960) that the total quantity of mucopolysaccharide carrying blood group specificity is the same in the saliva of secretors and nonsecretors and of patients with and without duodenal ulcer, with the inference that differences in susceptibility to duodenal ulceration do not depend upon differences in the quantity of such mucopolysaccharide which is available for mucosal defence. It is possible that any difference is qualitative rather than quantitative, and that mucus which is largely Le ${ }^{a}$-specific is less efficient in this respect than mucus which is not.

\section{Summary}

The ABO group has been determined in 390 Nigerians of both sexes with duodenal ulcer, and the secretor status and Lewis group in 172 male patients. There was an excess of people of group $O$ and of $A B O$ nonsecretors among these patients by comparison with control subjects drawn from the same tribe.

The excess of non-secretors was entirely made up of patients who were $\operatorname{Le}(a+b-)$, and there were fewer than the expected number of $\operatorname{Le}(a-b-)$ non-secretors. Among secretors the relative frequencies of $\operatorname{Le}(a-b+)$ and Le $(a-b-)$ subjects did not suffer from those found among the controls.

It is suggested that the enhanced liability of $\mathrm{ABO}$ non-secretors to duodenal ulcer depends upon the interaction of the secretor and Lewis genes.

My thanks are due to the physicians and surgeons who allowed me access to their patients, and to Professor Alexander Brown and Dr. K. Cobban for giving me facilities in their departments. I am especially grateful to Dr. Sheila Worlledge for constant help and advice. for providing the antisera, and for permission to quote the $\mathrm{ABO}$ groups of the blood donors.

\section{REFERENCES}

Barnicot, N. A., and Lawler, S. D. (1953). Amer. J. phys. Anthrop., 11, 83.

Brendemoen, O. J. (1949). J. Lab. clin. Med., 34, 538.

Brown. P. C., Glynn, L. E., and Holborow, E. J. (1959). Vox Sang (Basel). 4. i.

Clarke, C. A., Wyn Edwards, J., Haddock, D. R. W., HowelEvans, A. W.. McConnell, R. B., and Sheppard, P. M (1956). Brit. med. J., 2. 725 .

Evans, D. A. P., McConnell, R. B., and Sheppard, P. M. (1959). Ihid.. 1. 6̈03.

Doll, R., Drane, H.. and Newell, A. C. (1961). Gut, 2, 352.

Evans. D. A. P. (1960) J. Lab. clin. Med.. 55. 386.

Miller, E. B., Rosenfeld. R. E., Vogel, P., Haber. G., and Gibbel, N. (1954). Amer. J. phys. Anthrop., 12. 427.'

Race, R. R., and Sanger, R. (1959). Brit. med. Bull., 15, 99. Woolf, B (1955). Ann. hum. Genet., 19, 251.

"There is still too little understanding in some quarters for the feelings of an elderly person who has to give up independence. possessions and a cherished home to spend his or her remaining days with a group of strangers. One reliable test which those concerned with the planning and running of residential homes might well apply. if they are in doubt, is to ask the question: Would I wish my own father or mother to live here? Every effort should be made to reproduce an atmosphere of 'being at home' by providing more single rooms, by allowing residents to hring their own furniture. and by keeping down rules and regulations to the irreducible minimum." (Annual Report. National Old People's Welfare Council, obtainable from 26 Bedford Square, London W.C.1, price 1s. 6d.) 